\title{
ИЗУЧЕНИЕ МЕХАНИЗМОВ МИКРОБНОЙ БИОРЕМЕДИАЦИИ ТЯЖЕЛЫХ МЕТАЛЛОВ НА ПРИМЕРЕ КОБАЛЬТА И МЕДИ
}

\author{
А.Н. Сизенцов ${ }^{1}$, Е.В. Сальникова ${ }^{1}$, Я.А. Сизенцов ${ }^{1}$ Т.А. Климова ${ }^{2}$ \\ ${ }^{1}$ Оренбургский государственный университет, г. Оренбург, пр. Победы, 13 \\ *e-mail: asizen@mail.ru \\ ${ }^{2}$ Федеральный исследовательский центр биологических систем и агротехнологий \\ Российской академии наук, г. Оренбург, ул. 9 января, 29
}

РЕЗЮМЕ. Одним из основных факторов антропогенного загрязнения окружающей среды различными химическими поллютантами является развитие горнодобывающей отрасли и цветной металлургии. Возможное и наиболее перспективное направление решения проблемы загрязнения окружающей среды и биоценозов, в частности тяжелыми металлами, - использование физиолого-адаптационных механизмов толерантности и биосорбции сапротрофной микрофлоры. Установлен высокий уровень ингибирующего действия исследуемых эссенциальных элементов при создании массированной катионной нагрузки на исследуемые микроорганизмы рода Bacillus с высоким уровнем сорбции меди и кобальта на поверхностных структурах бактериальных клеток.

КЛЮЧЕВЫЕ СЛОВА: биоаккумуляция, медь, кобальт, диффузия, атомно-силовая микроскопия.

\section{STUDY OF THE MECHANISMS OF MICROBIAL BIOREMEDIATION OF HEAVY METALS BY THE EXAMPLE OF COBALT AND COPPER}

\author{
A.N. Sizentsov ${ }^{1 *}$, E.V. Salnikova ${ }^{1}$, Yu.A. Sizentsov ${ }^{1}$, T.A. Klimova ${ }^{2}$ \\ ${ }^{1}$ Orenburg State University, 13, Pobedy ave, Orenburg, Russia, 460018 \\ *e-mail: asizen@mail.ru \\ ${ }^{2}$ Federal Research Centre of Biological Systems and Agro-technologies of the Russian Academy of Sciences, \\ 460000 Orenburg, ul. 9 Yanvarya 29
}

ABSTRACT. The development of the mining industry and non-ferrous metallurgy is one of the main factors of anthropogenic pollution of the environment by various chemical pollutants. One of the possible and most promising direction for solving the problem of environmental pollution and biocenoses, in particular with heavy metals, is the use of physiological adaptive mechanisms of tolerance and biosorption of saprotrophic microflora. A high level of inhibitory action of the investigated essential elements was established when creating a massive cationic load on the studied microorganisms of the genus Bacillus with a high level of sorption of copper and cobalt on the surface structures of bacterial cells.

KEYWORDS: bioaccumulation, copper, cobalt, diffusion, atomic force microscopy.

\section{ВВЕДЕНИЕ}

Развитие горнодобывающей отрасли и цветной металлургии становится одним из основных факторов антропогенного загрязнения окружающей среды различными химическими поллютантами. Возможным и наиболее перспективным направлением решения проблемы загрязнения окружающей среды и биоценозов, в частности тяжелыми металлами, является использование физиолого-адаптационных механизмов толерантности и биосорбции сапротрофной микрофлоры.

Цель исследования - изучение механизмов микробной биоремедиации тяжелых металлов на примере кобальта и меди.

\section{МАТЕРИАЛЫ И МЕТОДЫ}

В качестве объектов исследования были использованы штаммы микроорганизмов рода Bacillus, входящих в состав пробиотических препаратов. В качестве регулирующих факторов в работе применяли стерильные водные растворы сульфата меди и кобальта. Критерием оценки наличия биоремедиационного механизма являлись: метод агаровых лунок с диффузией катионов в толщу агаризованного субстрата, совмещенный с методом серийных разведений (Sizentsov et al., 2018), 
нефелометрический метод определения относительной оптической плотности, атомно-силовая микроскопия (Sizentsov et al., 2021).

\section{РЕЗУЛЬТАТЫ И ОБСУЖДЕНИЕ}

Полученные экспериментальные данные свидетельствуют о наличии выраженного ингибирующего действия высоких концентраций катионов исследуемых металлов в отношении изучаемых микроорганизмов. Следует отметить, что исследуемые химические соединения оказывают выраженное пролонгирующее действие на фазу активного роста, увеличивая срок наступления стационарной фазы роста в диапазоне от 6 до 9 часов.

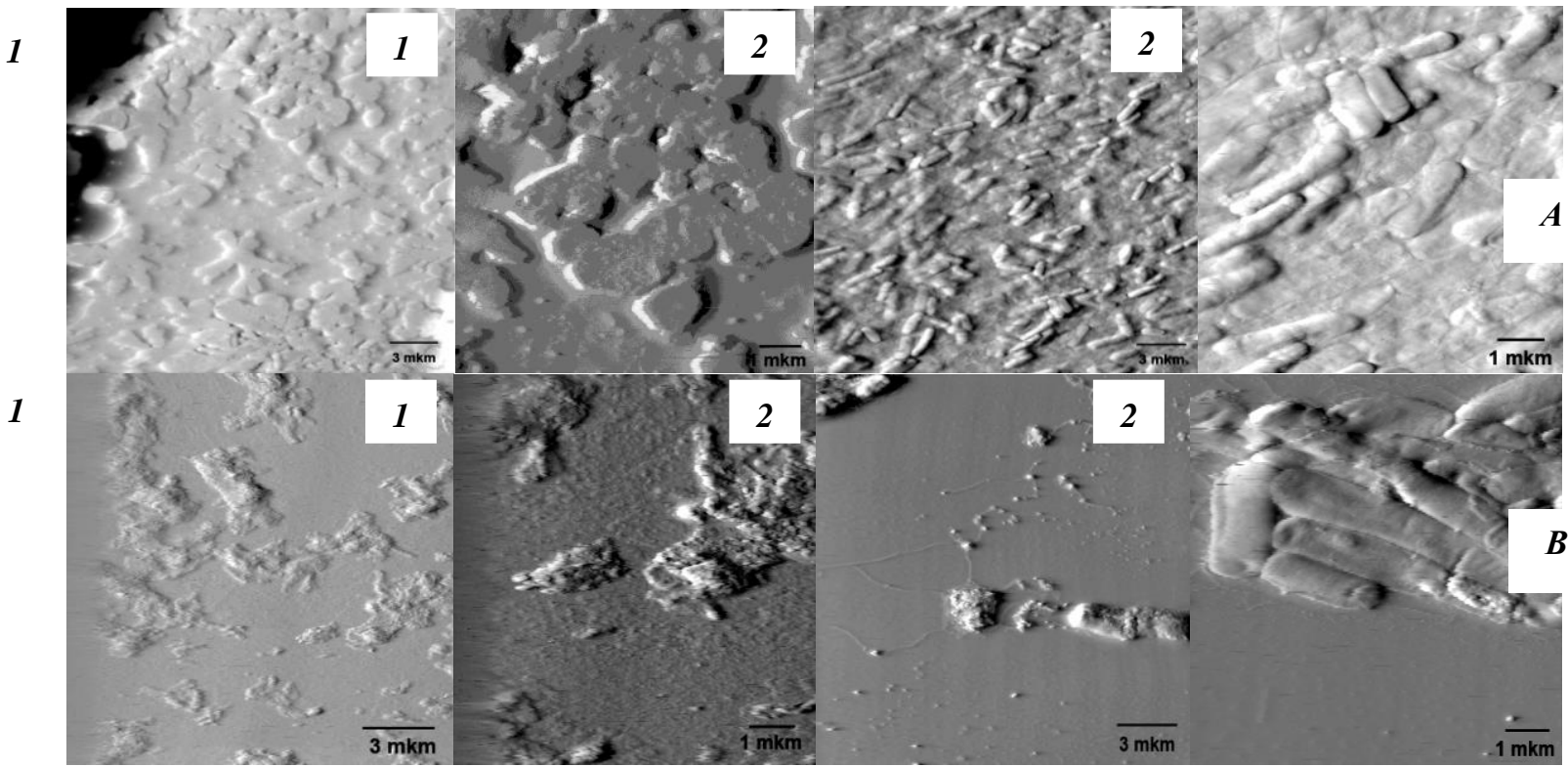

Рисунок. Оиенка биосорбции катионов меди и кобальта исследуемыми микроорганизмами на примере B. subtilis 534 с использованием атомно-силовой микроскопии (увеличение 3 и 1 мкм):

$A$-медь; $B$ - кобальт (1 - зона ингибирования роста, 2 - пограничная зона ингибирования и субингибирования роста)

Тенденция низкого уровня толерантности бактериальных штаммов к действию эссенциальных элементов гипотетически обусловлена отсутствием механизмов детоксикации в отношении жизненно важных элементов. В подтверждение выдвигаемой гипотезы следует отметить отсутствие спорулирующих форм микроорганизмов во всех исследуемых образцах (рисунок).

\section{ВЫВОДЫ}

Наиболее выраженный депонирующий эффект биологически доступных наноструктурных форм металлов регистрируется при взаимодействии тестируемых микроорганизмов с катионами меди с максимальным их депонированием в структуре популяции.

\section{Список литературы / References}

1. Sizentsov A.N., Cherkasov S.V., Karpova G.V., Bibartseva E.V., Kvan O.V., Kunavina E.A., Levenets T.V., Strekalovskaya A.D. The technology of chemical compound biotoxicity assessment by the method of agar basins. International Journal of Mechanical Engineering and Technology (IJMET). 2018; 9(11): 455-446.

2. Sizentsov A., Davydova O., Nikiyan H., Sizentsov Ya., Barysheva E., Bykov A. Assessment the technology for heavy metal biotoxicity and biosorption by bacterial cells. Biochem. Cell. Arch. 2021. 21(1): 901-906. 